\title{
Analysis on the Wealth Structure of Chinese Traditional Society from the Perspective of Social Class in Ming Dynasty
}

\author{
Yan Huang, \\ ${ }^{1}$ School of Wealth Management, Shandong Technology and Business University, Yantai, Shandong, China \\ *Corresponding author. Email:15963500101@139.com
}

\begin{abstract}
Since the middle of the Ming Dynasty, the market commodity economy was active, private wealth accumulated rapidly, and the relationship between social production and life had undergone profound changes. However, the rigid centralized system and the corrupt system of government officials promoted the severe polarization and division of social wealth distribution, which intensified social conflicts and eventually led to the demise of the Ming Dynasty. This article analyzes the wealth structure of Chinese traditional society from the wealth distribution of the clan aristocrats, officials, and wealthy businessmen, and discusses the influence of this structure on the development of Chinese history.
\end{abstract}

Keywords: Ming Dynasty, Wealth structure, Social class.

\section{INTRODUCTION}

The Ming Dynasty (1368-1644) lasted for 276 years and was the last feudal dynasty established by the Han nation in the history of traditional Chinese society. During the Ming Dynasty, the history of China was profoundly affected by the development of the global economy for the first time. From secluding the country from the outside world to the opening, the market commodity economy developed actively, and the bud of capitalism appeared several times. During this period of time, private wealth accumulated rapidly, which had a significant impact on the mobility of social class and national macro policies. The government of Ming Dynasty also tried to redistribute private wealth through multiple channels due to the country's fiscal difficulties. Some of these attempts had produced good results because they conformed to the Chinese national wealth ethics, and some had completely failed due to system design flaws or implementation deviations. At the middle and late stage of Ming Dynasty, it was a society with active market economy and a highly centralization system. It is of considerable practical reference value to analyze the source of these private wealth and social influence.
To analyze the structure of social wealth, it is required to look at the overall wealth of the society. According to the research data of Guan Hanhui and Li Daokui, the economic level of the Ming Dynasty (1402-1626) was generally in a state of slow growth and extremely low per capita economic growth. The rate was $0.29 \%$, which was basically an economic structure dominated by agriculture. The average value of agricultural output in the entire economy was as high as $88 \%$. In the middle and late stage of Ming Dynasty, it was considered to be a climax of the Chinese market and commodity economy. However, due to the high investment of commercial capital in land, handicraft and commerce did not exceed $20 \%$ at the peak. Due to the explosive population growth, the total economic growth was limited while the per capita income was hovering at a very low level, only reaching more than one-third of the British's income before the industrial revolution [1].

In ancient Chinese history, there had always been large errors in population statistics. Because of corvee and poll tax, taxpayers had to hide the population for tax avoidance. Therefore, under normal circumstances, official data would be smaller than the real population figure. Before the Ming Dynasty, the peak population counted by the 
Ministry of Revenue in feudal China had been below 70 million. Therefore, traditional historians believed that the ceiling of China's population was 100 million for the dynasties before Ming Dynasty. He Bingdi's estimate of the actual population of China at the end of the 14th century was "roughly more than 65 million, and may reach a larger unknown." $[2]^{\mathrm{P} 10} \mathrm{He}$ believed that the Chinese population reached 130 million to 150 million by the 28th year of Wanli Period (1600). [2] ${ }^{\mathrm{P} 310}$ With pressures brought by the rapidly growing population, it first faced the huge demand for food. Therefore, the basic field of wealth production in the Ming Dynasty was firstly agriculture, followed by handicraft industry and the commodity trade. From the perspective of the economic structure in the middle and late stage of Ming Dynasty, the output value of handicraft in the total economic output also increased rapidly, which promoted the prosperity of the domestic commodity market and expanded the scale of overseas trade. This adjustment of the market structure directly transformed a considerable amount of the agricultural population into professional handicraft and commercial labor, which in turn contributed to the emergence of occupational employmentproduction relationship with the bud of capitalism in the south of the Yangtze River.

Another noteworthy wealth phenomenon in the Ming Dynasty was the silverization of currency. The Ming Dynasty was a period when China changed a tax on goods in kind to a currency tax. After the single-whip-tax reform, the labor tax was officially converted into a currency tax. This largescale monetization of taxes put forward higher requirements on the government's financial control ability, especially the macro-control ability of currency circulation. In the early Ming Dynasty, strict legal measures were used to promote banknotes throughout the country. However, due to the absence of a strong banknote preparation system, the market could not circulate smoothly. Therefore, the main currency of the Ming Dynasty was weighed silver. With the value of precious metals as their currency measurement, the government of Ming Dynasty was unable to control the currency value through the central issuance of banknotes or metal currency, as China's previous dynasties had done, thus affecting the relative price system. It completely lost the ability of macroeconomic financial regulation and control, as well as the economic flexibility of tax and other fiscal revenue, and lost the ability to protect its economy through exchange rate settlement in international trade. There was a huge demand for silver itself due to the silverization of Chinese currency, and China became the most important country to import silver at that time. Wan Ming believes that "from 1540 to 1644, China imported approximately 75 tons of Japanese silver through Southeast Asia each year, totaling 7,500 tons. The total amount of silver imported through Europe is about 5,000 tons, and the total amount of American silver imported through the Philippines is about 7,620 tons." [3] On the one hand, the government had completely lost control over the currency. On the other hand, silver had become the equivalent of wealth, causing competition for resources from the royal family, officials, merchants, clans, and civilians at that time. Against the above background, this article selects four perspectives to analyze the wealth structure of the Ming Dynasty: vassal aristocrats, officials, wealthy merchants and clan.

\section{THE MAIN WEALTH COMPOSITION OF THE VASSAL ARISTOCRACY}

As a social production structure dominated by agriculture, land is the most important wealth in Chinese traditional feudal society. In order to maintain the grand unification, various dynasties generally preached that "the whole world belongs to a king". In fact, the "public land" system that appeared in the state-owned form and the "private land" system that appeared in the landlord-owned form were implemented. In ancient Chinese society, although each dynasty had a different system design, only the upper class and the lower class could participate in land ownership. The upper class consisted of the royal family, clan families, officials, and their affiliated interest groups. In the early days of each dynasty, an emperor with highly centralized power held the dominant power in resource allocation. From the time when the princes were entrusted in the Western Zhou Dynasty, the royal family members, who were the main relatives of the emperor, naturally became the biggest beneficiaries of the distribution of land other than the emperor.

The Ming Dynasty was also a dynasty where public land system and private land system were implemented. In order to maintain the imperial power, the Ming Dynasty adopted a system design that gave preferential treatment to the clan in terms of material and economy and weakened the power of the clan to the utmost politically, that is to "give special treatment to clan". In the salary standard 
(1935) that was later implemented in the entire Ming Dynasty, the highest-ranking prince's annual salary was 10,000 dan of rice ( 1 dan $=70.8 \mathrm{~kg}$ ), while the highest-ranking official's annual salary was only 1044 dan. In addition to the annual salary, the greater wealth of the clan aristocrats was the land they owned. On the one hand, it was the land allocated according to the system or directly granted by the emperor according to his own clan status. No matter what level of clan family members were, they could have a certain amount of tax-free land as permanent private property when they were adults. On the other hand, the nobles would also rely on their power to occupy the other land. Before the middle of the Ming Dynasty, the economic center of the clan and aristocrats was still mostly in the south. After the period (1436-1449), due to the country's need for defense, the north received more and more attention, and a large number of noble manors quickly emerged in the capital city and its environs. In 1489, Li Min, who was appointed as the head of the Ministry of Revenue in feudal China, reported to the emperor that in addition to the five imperial estates owned by the imperial family, in the Gyeonggi area, clan relatives occupied 332 manors, covering an area of more than 33,100 hectares, and they were expanding. After the "Civil Change" in 1449, the farmland in the northern border provinces that was abandoned due to the retreat of the army became wasteland, which was also taken as manors by the nobles in the capital.

There were 62 princes in the Ming Dynasty, and 50 princes went to their feudal domains, all of which owned large-scale finca. These villages were mainly concentrated in Shandong, Shanxi, Shaanxi, Henan, Sichuan, Hunan, Guangdong and Jiangxi. In addition to the legally rewarded land, the amount of official and private land occupied and invaded by bigwigs was also quite large. The occupied official fields include military farms, pastures for horse, coastal salt fields, wetlands, inland rivers and lakes, and wetlands. The occupied private land included the non-taxable land with tax reduction and exemption by the government, the land that was directly purchased regardless of land type, grade, or from land-holding peasants at low price, or the land obtained by creating trouble traps. According to Deng Bin's research, by the late Ming Dynasty, the princes and other clans occupied more than 110,000 hectares of land, the six immediate princes occupied more than 90,000 hectares of land, the collateral 23 princes occupied more than 120,000 hectares of land, and the clan relatives occupied more than 330,000 hectares of land [4]. These clan relatives had tax-exempt privileges. On the one hand, they forced land-lost farmers to become "tenant farmers"; on the other hand, they squeezed the government's tax sources. After more than 200 years of development in the late Ming Dynasty, the government's taxable land had not increased, but decreased instead.

There were 58 clan relatives in the early Ming Dynasty. However, with the rapid population growth, it had expanded to 80,000 in the late stage of Wanli period (1573-1620). The increase in the population of the clan relatives brought a corresponding rigid increase in national salary expenditures, and the national finance was already overwhelmed. The extremely uneven distribution of wealth brought about by the policy of "giving special treatment to clan relatives" became an important cause of the financial crisis in the Ming Dynasty. In the forty-first year of Jiajing period (1562), Lin Run, the supervisory censor, submitted a written statement that according to the nation's fiscal tax revenue, four million dan of grain were supplied to the capital, while the salaries that should be received by the clan relatives according to the patriarchal clan system was 8.53 million dan, which was double the income of the central government. And the reform of the salary system was urgent.

In addition to land and salaries, the clan relatives were also involved in commerce, handicrafts, and financial credit industries. They opened stores in cities and border areas, collected business taxes, occupied and operated coal and various mines, and involved in ceramics and other handicraft production, etc. [5]

\section{SALARIES AND OTHER WEALTH OF THE OFFICIALS}

In the early Ming Dynasty, the emperor Zhu Yuanzhang, who was born as a low-level civilian, formulated extremely low official salaries in order to curb the official corruption, and enacted extremely stringent legislation on official corruption. Throughout ancient Chinese history, the salary of officials in the Ming Dynasty was the lowest. According to "The History of Ming Dynasty" compiled in the Qing Dynasty, "the official salary has been low since ancient times, and there was no such low salary other than that in Ming Dynasty." [6] ${ }^{\mathrm{P} 2003}$ Unfortunately, the low salary did not bring the government of Ming Dynasty a clean atmosphere, but greed instead. The 
low salary system of Ming Dynasty mainly included three aspects. First, the salary of Ming Dynasty was the lowest. In the official system of Ming Dynasty, there were a total of 18 grades from the first grade to the ninth grade. The official who was at the highest grade would have 1044 dan of rice per year, and the official who was at the lowest grade would have only 60 dan of rice per year [6]P2002. The official salary of Ming Dynasty was very different from that of other dynasties or the aforementioned salary of clan relatives. Second, the government of Ming Dynasty abolished the land owned by the officials. In other dynasties, they would give officials land other than salary, so as to complement the salary with the land income. In the early Ming Dynasty, the official land was abolished, and the salary was entirely sent by the government. Thirdly, the government would send other things to replace the salary rice, which was the core content of the salary system of Ming Dynasty. The socalled salary system of Ming Dynasty refereed that the salaries paid by the government was converted from grain in the nominal salaries into currency such as banknotes, textiles, pepper and other physical objects. The replaced items were not based on the needs of officials, but based on the quantity of goods in the government treasury. The standards were significantly lower than the normal market prices. As for giving banknotes, as mentioned above, due to the gradual depreciation of banknotes in the Ming Dynasty, it was like waste paper being abandoned by the market, and people took weighing silver as currency. However, the official salary was still issued with banknotes, meaning that the salary was reduced. According to Wan Qi's research, compared with the average income of other classes in the Ming Dynasty, the annual income of land-holding peasants who owned an area of $50 \mathrm{mu}$ during the Wanli period of the Ming Dynasty was about 70 dan of rice, and the annual land lease for the small and medium landlord who owned 100 mu was about 100 dan of rice, the lowlevel unskilled workers could buy about 12-13 dan of rice, and the skilled workers could buy about 36 dan of rice. The officials at the lowest level could earn about 60 dan of rice per year, which was still above the middle level at that time. However, this was just the official salary. According to Wan Qi's calculations, "the overall rate of official salaries has fallen by $42 \%$ after the discount, and the overall average salary of 18 levels before the discount is 307.6 dan of rice. However, after the discount, the average salary is only 177.7 dan of rice." [7] Highranking officials, such as the officials who were at the fifth level or above, had the largest discount, while the nominal salary of low-level officials was originally low, and there was not much left after the discount. Therefore, the discount of the salary was an important direct cause of the low official salary of the Ming Dynasty. This kind of salary system greatly promoted the officials' motivation to obtain wealth from other channels, including participation in commercial operations, participation in capital gains such as usury, and extra-legal income such as corruption.

In the mid-Ming Dynasty, the fiscal deficit increased. In order to reduce administrative costs, officials' salaries were continuously discounted. In order to alleviate conflicts, the government increased preferential policies for bureaucrats in system design. Tax reductions and exemptions within and outside the various systems facilitated officials to obtain wealth through legal and illegal means, such as cooperating with local business associations, promoting investment of interest partners in education, increasing political discourse power through the admission of civil servants, and seeking political rights with political capital. The "squirearchy class" composed of bureaucrats temporarily residing in their hometown and the retired officials served as the leaders of the township. They were connected with each other and obtained greater benefits through the control of grassroots social organizations. There were also officials who used land transactions or their taxexempt status to operate land for others. They put capital into the land market to achieve the merger of the land, or put capital into the financial market as usury capital through commerce, pawn and other channels. In addition, officials would obtain illegal profits in the field of state monopoly through power in their hands, and extra-legal income through acts such as corruption and bribery.

It is worth mentioning that officials in the Ming Dynasty were corrupt. At the beginning of the Ming Dynasty, the clean government was highly valued when the country was founded. Later, the corruption of all the government from top to bottom, such as civil and military officials, clan relatives, and even emperors was thought-provoking.

From the perspective of basic-level officials, the Lijia system in the Ming Dynasty was basic-level social management and taxation system. As leaders, borough warden and elder would help the government to receive the tax. Throughout the entire ancient history of China, the grassroots social management was either done by the clan based on blood ties, or managed by local capable personnel 
based on geography. Some of these people were local small and medium-sized landlords, and some were powerful locals who dominated the countryside. Under the guise, they colluded with the corrupt state and county officials in the government, the borough warden bribed the subordinates to seek privileges, and the subordinates used the borough warden to embezzle property. When Hai Rui visited Songjiang in the Ming Dynasty, there were tens of thousands of civilians "suing the township officials to seize property" [8]. The corruption of the grass-roots officials ultimately destroyed the Lijia system, and the large-scale flow of people and households was difficult to control, which made it necessary to carry out the reform of the tax and servitude system in the middle stage of Ming Dynasty.

From the perspective of senior officials, Yan Song, the first assistant of Jiajing period, was very typical. Yan Song's family was in abject poverty when he was a child. From 1507 when he joined the Imperial Academy to 1562 when he returned home, he accumulated 4 million taels of property, including 1 million mu of land and more than 8000 houses in the capital, Jiangxi, Nanjing and other places. Only these properties are many times the salaries of Yan Song's grandparents and grandchildren who worked in the government [9]. After the Military General Li Zicheng occupied Beijing, he recovered 70 million taels of silver to help for soldier's pay and provisions. At that time, the government's tax revenue was only 3.2 million taels in the late Ming Dynasty. "Among the 70 million taels of silver, $80 \%$ were paid by nobles and eunuchs, and $20 \%$ by merchants" [10]. Of course, there was a factor of torture and coercion, which reflected the huge amount of wealth owned by officials at that time from another perspective. Just as Hai Rui said in 1566, "in Jiajing period, households have no money." [11] After the distribution to the royal family, the clan and the officials, the resources and wealth left to the ordinary people were very few.

\section{THE CAPITAL OPERATION AND SOCIAL INFLUENCE OF THE ENRICHING PEOPLE AND BUSINESSMEN}

The academic circles have different opinions on the definition of "enriching the people". This paper tends to Lin Wenxun's view that "enriching the people" refers to "a social group with wealth and higher education but no privileges, which is rooted in the interwoven development of natural economy and commodity economy" [12]. The industry involved by this group covered agriculture, commerce, handicraft industry, mining industry, and even some of them were engaged in agriculture, industry and commerce, involving all fields of social economy, forming a unique rich society in China during the Ming and Qing Dynasties. For example, in the early Ming Dynasty, the essence of liangzhang system (tax collection) was to make the rich people to be the chief. In addition to being responsible for collecting taxes, arranging labor and transferring taxes to the government, the chief of tax collection system had the responsibility to make up for the poor people who could not pay taxes in the region, so as to complete the tax collection in the region. Nobles, officials and even scholars who had obtained the corresponding status according to the regulations all had the privilege of tax exemption. Only the rich people who had land but no privilege became the basis of national taxes, and the rich people became the main undertaker of national taxes.

The rich people in Ming Dynasty could be divided into several groups according to their industries, among which the most powerful was the new merchant class. After recuperation in the early Ming Dynasty, the economy of the Ming Dynasty recovered and began to develop rapidly, and the domestic market expanded greatly. By the middle of the Ming Dynasty, the silver currency was generally realized, the national business became popular, a large number of regional merchant groups appeared, and the form of civil society and the structure of social production also changed significantly. The traditional "scholars, farmers, workers and businessmen" were despised by the world. Merchants at the lowest class were promoted in social status, and had their own power through the integration of government and business, agriculture and business, and became the main body of the "rich people class" in Ming and Qing Dynasties.

Around the 16th century, China's private commercial capital was already quite abundant. Some of the merchants maintained the relationship with the rural society by purchasing land, and some of them completely separated from agriculture through financial credit and even international trade. However, no matter what industry they were in, these merchants had great capacity for behavior. In the Ming Dynasty, merchants in the form of regional business groups, such as Hui merchants, Jin merchants, Guangdong merchants, $\mathrm{Su}$ 
merchants, Zhejiang merchants and Shandong merchants, set up guilds and offices all over the country to protect the interests of their fellow countrymen, and organizations in the form of trade unions to protect the rights and interests of their peers. The two sometimes intersected. For example, Hui merchants had capital all over the country and owned the industries, such as the salt industry, grain, wood, medicinal materials, tea, stationery and so on. Also, they were involved in overseas trade. Based on the northern region, Shanxi merchants initially engaged in grain and salt related to the cultivation of farmland in northwest China. Later, they opened up the financial field and began to operate Shanxi Bank.

A very important source of the wealth of the rich businessmen was the benefits brought by the integration of government and business. In the early Ming Dynasty, businessmen cooperated with the officials to seek the monopoly profit through illegal means, and later legalized it by influencing the policy-making through the spokesperson who worked in the government. Taking Shanxi merchants as an example, at the early stage, Shanxi merchants operated private salt by bribing officials because of their geographical advantages of being close to the northern border of the country. Since the middle of Ming Dynasty, the monopoly of salt industry could not be maintained, and the government began to try to allow private capital to enter. However, Shanxi merchants had been operating in this industry for many years. At this time, with its strong economic strength, they divided up the market distribution of salt industry and improved the circulation efficiency. Through Zhang Siwei, Wang Chonggu and others, Shanxi merchants actively promoted border trade with Mongolia. Wang and Zhang families were the actual leaders of Shanxi merchant group, which can be seen from the integration of government and business. The development of Shanxi merchants was synchronized with the prosperity of the northern border areas. With the deepening of mutual market, the backward frontier areas had also achieved rapid development. Datong's prosperous market had become the pearl of the north. Shanxi businessmen had promoted and led the border trade for more than 100 years.

Another thing that cannot be separated from wealth was the integration of commerce and agriculture in Ming Dynasty. In the middle stage of Ming Dynasty, the private manor economy began to show a strong momentum of development. Some rich people with financial resources and status competed to buy land, and the concentration of real estate gradually increased. In addition to nobility and officials, there were also quite a number of large real estate owners among rich people. For example, in Dongting, Wuxi County, Changzhou Prefecture, the rent of Hua family could reach 480, 000 per year [13]. According to "the development of He family", He Tuyuan, a wealthy man in Zhongshan County, Guangdong Province, bought more than $20000 \mathrm{mu}$ of land with a huge amount of silver accumulated for a long time during the reign of Zhengtong and Jingtai, earning tens of thousands dan of rice yuan every year. In Ming Dynasty, it was a common phenomenon that the rich people had the dual status of merchants and landlords. After gaining commercial profits, merchants tended to buy land and collect land rent.

In fact, in the Ming Dynasty, the return rate of land rent was far lower than the commercial profit rate. According to Ye Xianen's calculation, after Wanli period, the annual land rent collected by Huizhou landlords was only $1 / 18$ to $1 / 8$ of the land price. In Ming and Qing Dynasties, the profit margin of $20 \%$ was already considered as the low level for the business." [14] However, due to the traditional idea of attaching importance to agriculture and the need to avoid higher commercial risks, many businessmen would seek "the rich at the end" and gradually became landlords. Their commercial profits were more or less turned into real estate and evolved into capital for rent. Throughout the Ming Dynasty, commercial capital had been active in the land trade market for a long time, and land capital became the destination of commercial capital incompletely.

Like the early drive of the western bourgeois revolution, the rich people with huge wealth began to demand social status and political discourse in the middle of Ming Dynasty. As mentioned above, the excessive tax collection caused by the financial difficulties of Ming Dynasty deeply hurt the interests of the rich people as the main taxpayers. For example, the "official disaster" in Jiangnan during the Wanli period was in fact the struggle for wealth between the royal family and the rich people in Jiangnan. As a class with resources but no voice, the rich class began to play a game with the government on the distribution of wealth by influencing the government's decision-making and other aspects. These games were found in "singlewhip-tax reform" and "three additional collections", which eventually led to the "party struggle" that the Ming government could not solve and the final demise of the Ming Dynasty. 


\section{CONCLUSION}

Qian $\mathrm{Mu}$ once pointed out that "modern China generally started from the Ming Dynasty" [15]. As an inflection point in Chinese history, the Ming Dynasty began to be embedded in the global economy, or actively or passively carried out profound transformation and change, presenting many phenomena of modern society. The later Qing Dynasty generally inherited the social and economic structure of the Ming Dynasty. From the macro level, the social wealth of the Ming Dynasty was transferred from the folk to the government through taxation and various levies. As the currency tax was the main body in the Ming Dynasty, the flow of resources was mainly completed by currency. And it flowed from the government to the folk through financial expenditure. However, in the Ming Dynasty, especially in the late Ming Dynasty, military expenditure and administrative expenditure occupied the vast share of the fiscal expenditure. In fact, the resources used for the folk were extremely limited. Then, there was the multi-dimensional flow realized through the exchanges of market commerce, handicraft industry, service industry and international trade. Of course, agriculture and land transactions were also deeply involved in this part of the flow. Due to the influence of silver currency, China not only began to accelerate the flow of wealth, but also was greatly affected by the influence from overseas markets.

\section{AUTHORS' CONTRIBUTIONS} Huang.

This paper is independently completed by Yan

\section{REFERENCES}

[1] Guan Hanhui, Li Daokui. "A Probe into GDP and Structure of Ming Dynasty" [J]. Economics (Quarterly), 2010, 9(03): 787-828. (in Chinese)

[2] He Bingli. Translated by Ge Jianxiong. "Population and Related Issues Since the Early Ming Dynasty: 1368-1953" [M], Beijing: Sanlian Bookstore, 2000. (in Chinese)

[3] Wan Ming. "Silver Monetization in the Ming Dynasty: A New Perspective of Connecting China to the World" [J], Hebei Academic Journal, 2004(3). (in Chinese)
[4] Deng Bin. "Disadvantages and Analysis of Land Property System in Ming Dynasty" [D]. Hebei Agricultural University, 2008. (in Chinese)

[5] Wang Yuquan. "The prince's cropland of the Ming Dynasty" [J], Collection of Historical Essays, 1964(1). (in Chinese)

[6] (Qing) Zhang Tingyu. "Ming History" (Vol. 82), "Shihuo VI". Beijing: Zhonghua Book Company, 1974. (in Chinese)

[7] Wan Qi. "Analysis of Civil Official Salaries in Ming Dynasty" [D]. Soochow University, 2011. (in Chinese)

[8] (Ming) Hai Rui. "The Collection of Hai Rui . The Remarks on Self-Reporting of Irresponsibility", Beijing: Zhonghua Book Company, 1962. (in Chinese)

[9] Zhang Xianqing. "The Story of Yan Gao", Hefei: Huangshan Publishing House, Chapter 22 _ "Huge Amount of Family Funds". (in Chinese)

[10] Zhang Dexin, Tan Tianxing. "The Biography of Emperor Chongzhen" [M]. Shenyang: Liaoning Education Press, 1993. (in Chinese)

[11] (Ming) Hai Rui. "Collection of Hai Rui" • "Public Security", Beijing: Zhonghua Book Company, 1962: 218. (in Chinese)

[12] Lin Wenxun. "A Study of the "Rich People" in Ancient China" [M]. Kunming: Yunnan University Press, 2008. (in Chinese)

[13] (Qing) Qian Yong. "Notes on climbing" quoted from "Suzhou Rural Economic Data in Ming and Qing Dynasties" by Hong Huanchun. Nanjing: Jiangsu Ancient Books Publishing House, 1988: 87. (in Chinese)

[14] Ye Xian'en: "Huizhou Rural Society and Tenancy System in Ming and Qing Dynasties", Hefei: Anhui People's Publishing House, 1983: 69. (in Chinese)

[15] Qian Mu. "The Success and Failure of Chinese Politics in Past Dynasties", Beijing: Jiuzhou Press, 2012: 102. (in Chinese) 